\title{
Seasonal progression of factors limiting phytoplankton pigment biomass in the Rhode River estuary, Maryland (USA). II. Modeling $\mathbf{N}$ versus $\mathbf{P}$ limitation
}

\author{
C. L. Gallegos* ${ }^{*}$ T. E. Jordan \\ Smithsonian Environmental Research Center, PO Box 28, Edgewater, Maryland 21037, USA
}

\begin{abstract}
Previously reported experiments demonstrated that $\mathrm{N}$ addition enhanced phytoplankton growth rate more frequently and to a greater extent than did addition of $\mathrm{P}$ alone. Here we develop a model of nutrient-limited net phytoplankton production for the Rhode River estuary, Maryland (USA), to determine the sensitivity of observed patterns to changes in the manner in which nutrients are delivered to the system. The model successfully reproduced the seasonal pattern of phytoplankton chlorophyll variation for an average year, the relative timing of $\mathrm{P}$ and $\mathrm{N}$ limitation, and the interannual variability in the timing of the shift from $\mathrm{P}$ to $\mathrm{N}$ limitation. Manipulation of nutrient sources in the model suggested that the disappearance of $N$ at the seaward boundary of the estuary is sufficient to produce the shift from P to N limstation. Raising the modeled N:P ratio of sediment nutrient release to a value greater than that of the phytoplankton biomass caused co-limitation by both $\mathrm{N}$ and $\mathrm{P}$ in the summer, but no manipulations produced limitation solely by $\mathrm{P}$ in the summer. In the model, different computed indicators of nutrient limitation (i.e. ratios of available N:P, physiological indicators of internal nutrient pools, and computed growth stimulation by nutrient additions) generally identified the same nutrient as limiting at a particular time. The model demonstrates how observed shifts in nutrient limitation result from changes in delivery of $\mathrm{N}$ and $\mathrm{P}$ from the watershed, from the sediment, and from incoming phytoplankton.
\end{abstract}

KEY WORDS: Phytoplankton - Estuary - Nutrients Modeling

\section{INTRODUCTION}

Estuaries have long been recognized as locations where significant transformations of river borne dissolved and particulate matter take place (Schubel \& Kennedy 1984). Water quality in estuaries, and the suitability of estuaries as habitat (e.g. for sport and commercial fisheries or waterfowl), are greatly influenced by the response of resident plankton communities to riverine inputs of nutrients and organic matter (e.g. Officer et al. 1984). The composition of water entering estuaries, in turn, depends on geological features and land use patterns in adjacent terrestrial

•E-mail: gallegos@serc.si.edu watersheds (e.g Jordan et al. 1991a). Because of the short generation times of phytoplankton, the relationships amongst estuarine plankton communities and hydrologically linked terrestrial and coastal systems encompass processes that occur across a range of scales from transient nutrient uptake kinetics (i.e. minutes; Fisher et al. 1992) to multi-annual drought cycles (Jordan et al. 1991b). Therefore, understanding the complex interactions between estuaries, adjacent coastal waters, and terrestrial ecosystems and predicting responses to changes in land use require integration of experimental studies, environmental monitoring, and hierarchically linked models of the relevant biological and biogeochemical processes.

As the composition of river flow responds to coastal development, deforestation, and changes in agricul- 
tural land use, it is important to know how patterns of nutrient limitation will be affected by changes in the sources, amounts, or relative proportions (i.e. N:P ratios) of nutrients in coastal waters. Several different methods have been used simultaneously, sometimes with equivocal results, to identify the nutrient most limiting to phytoplankton in estuaries (Paasche \& Erga 1988, Fisher et al. 1992, Pennock \& Sharp 1994). Under what conditions might nutrient ratios, growth rate stimulation, and physiological indicators of cellular nutrient status give congruent or conflicting indications as to the nutrient most limiting at a particular time? This question is difficult to address because whole ecosystems are generally neither replicable nor amenable to experimental manipulation. Furthermore, some important physiological measurements cannot be routinely monitored on natural phytoplankton communities. However, impossible measurements and experiments could be simulated with a suitable model in which the physiological status of phytoplankton cells can be calculated. For example, such a model could reveal the effects of nutrient additions at times when the expected responses are below experimental detection limits, as in early spring when temperature and insolation are low.

In the companion paper (Gallegos \& Jordan 1997 in this issue) we reported experimental studies on the seasonal roles of physical factors, microzooplankton grazing, and nutrients in limiting phytoplankton growth in $1 \mathrm{~d}$ incubation experiments. Nutrient addition never stimulated phytoplankton growth before mid-April. However, addition of $\mathrm{N}$ enhanced growth in about $70 \%$ of experiments in summer, and about $50 \%$ of experiments in autumn, while addition of $P$ enhanced growth only in late spring and autumn. Growth enhancement by $\mathrm{P}$ addition was often lower than the level of reliable detection, and generally less than $N$ addition in summer.

In this paper we use models to address questions beyond the reach of our previous empirical studies. We use observed relationships between growth rates and environmental factors to develop a model of nutrientlimited phytoplankton growth based on that of Riegmann \& Mur (1984). We then combine the growth model with a model of estuarine mixing that includes seasonally varying boundary conditions and environmental forcing functions. We also use the model to calculate several indicators of nutrient limitation, including ratios of dissolved available nutrients, physiological status based on internally stored nutrients, and net growth rate stimulation by $\mathrm{N}$ or $\mathrm{P}$ (or both) addition. We then use the model to examine the patterns of nutrient limitation predicted by various alterations in the ratios of $\mathrm{N}$ and $\mathrm{P}$ inputs. We use the combined model to determine the sensitivity of $P$ and $N$ limitation to the manner in which nutrients are supplied.

\section{METHODS}

Study site. The Rhode River $\left(38^{\circ} 53^{\prime} \mathrm{N}, 76^{\circ} 32^{\prime} \mathrm{W}\right.$; Fig. 1) is one of several tributary embayments or subestuaries on the western shore of the mesohaline region of Chesapeake Bay in Maryland, USA. It is 550 ha in area. Depth at mean low water varies from $4 \mathrm{~m}$ at the mouth to $<1 \mathrm{~m}$ in the upper subtidal regions. Land composition in the 2300 ha watershed of Muddy Creek, the principal freshwater source to the upper subestuary, is mostly forest and farms (Jordan et al.

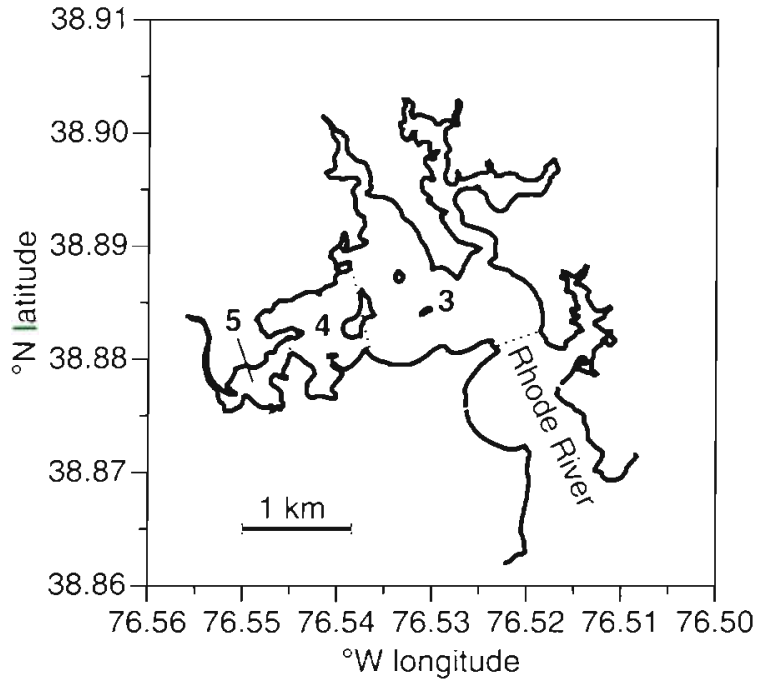

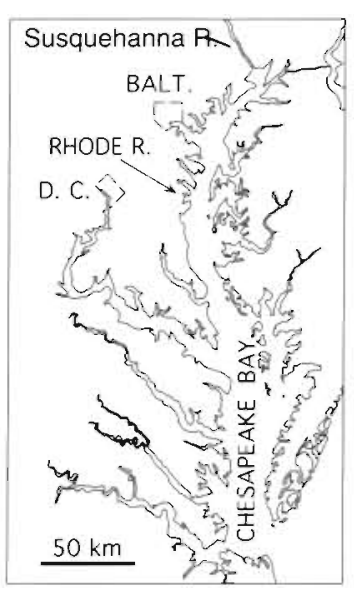

Fig 1 Map of the Rhode River, Maryland (USA), showing segment designations (numbers) and boundaries (dotted lines) used for modeling. Panel at right shows location of the Rhode River along the main axis of Chesapeake Bay in relation to the cities Washington, DC (D. C.) and Baltimore, Maryland (BALT.), USA 
1991a). For purposes of sampling and modeling we have divided the subestuary into segments numbered sequentially from 1 seaward of the mouth to 7 and 8 representing the 2 most landward of the tidal branches (Fig. 1). This analysis focuses on segments 3 to 5 , a region influenced both by Muddy Creek and by the Susquehanna River (Gallegos et al. 1992).

The Rhode River is eutrophic. Long-term average chlorophyll concentrations during summer in segment 4 were about $50 \mathrm{mg} \mathrm{m}^{-3}$ from 1978 to 1989 (see Jordan et al. 1991a), but in recent years the summertime average has been 25 to $30 \mathrm{mg} \mathrm{m}^{-3}$. Seasonally averaged concentrations of dissolved inorganic phosphate (DIP) in segment 4 range from $<0.1$ to $1.4 \mu \mathrm{M}$, and from $<0.2$ to $36 \mu \mathrm{M}$ for nitrate (Jordan et al. 1991a).

Experimental procedures. To assess performance of the model we compared simulations of phytoplankton chlorophyll with measurements made on depth-integrated samples collected from segment 4 (Fig. 1) at weekly intervals in 1991. Samples for chlorophyll analyses were filtered onto Whatman GF/F glass fiber filters and extracted in $90 \%$ acetone at $4^{\circ} \mathrm{C}$ in the dark for about $18 \mathrm{~h}$. For continuity in long-term data sets, chlorophyll concentrations used in modeling seasonal patterns of phytoplankton biomass in situ were calculated from absorbances measured spectrophotometrically (Jeffrey \& Humphrey 1975).

We used the model to predict growth rate enhancement by additions of $\mathrm{N}$ and $\mathrm{P}$. Then we compared the model predictions with bioassay measurements of growth rate enhancements. Complete methods for the bioassays are given in the companion paper (Gallegos \& Jordan 1997). Briefly, the experiments combined the dilution technique (Landry \& Hassett 1982, Gallegos 1989) with nutrient additions in a design similar to that of Andersen et al. (1991) and Elser \& Frees (1995). Duplicate incubations with either added N, P, or neither (i.e. ambient nutrients) were conducted at dilution levels $D=1.0,0.4$, and 0.05 , where $D$ is the fraction of unmodified estuary water in the incubation. The addition of nutrients at different dilution levels allowed us to examine the interaction between grazing and nutrient supply in controlling growth. Chlorophyll concentrations in dilution experiments were calculated from fluorescences read on a Turner Designs 10-AU fluorometer before and after acidification (Holm-Hansen et al. 1965). Growth rates were calculated from changes in chlorophyll concentrations in the standard manner as $\ln \left[B_{24}(D) / B_{0}(D)\right]$, where $B_{0}$ and $B_{24}$ are, respectively, the initial and final chlorophyll concentrations at dilution level $D$. Growth enhancement was calculated as the maximal difference between growth rates in ambient nutrients and growth rates in the treatment (i.e. $+\mathrm{N}$ or $+\mathrm{P}$ ) consistently giving the highest rates.

\section{MODEL DEVELOPMENT}

\section{Model structure}

Building on previous models of the Rhode River (Han 1974, Jordan et al, 1991a, Gallegos et al. 1992), we represent the subestuary as a series of well-mixed segments, which exchange contents with neighboring segments (numbered as in previous models, e.g Jordan et al. 1991a, Gallegos et al. 1992). Our model focuses on a segment (4) where we performed our growth experiments and on the adjacent upstream and downstream segments ( 5 and 3 ).

State variables in each segment, $i(=3,4,5)$, are concentrations of dissolved inorganic nitrogen, $N(\mu \mathrm{M})$, and phosphorus, $P(\mu \mathrm{M})$, and phytoplankton chlorophyll, $C\left(\mathrm{mg} \mathrm{m}^{-3}\right)$, as well as 2 pools for each nutrient contained in the phytoplankton (see below). Definitions of symbols are given in Table 1. Mass balance equations for concentrations in each segment are of the form

$$
\frac{\mathrm{d} X_{i}}{\mathrm{~d} t}=q_{i-1,1}\left(X_{i-1}-X_{1}\right)+q_{1,1+1}\left(X_{i+1}-X_{1}\right)+\sum S_{i}^{X}
$$

where $X=N, P, C$, or internal nutrient pools in segment $i, q\left(\mathrm{~d}^{-1}\right)=$ mixing coefficients between adjacent segments, and $\sum S_{i}^{X}$ (concentration units $\mathrm{d}^{-1}$ ) $=$ the sum of all sources and sinks of constituent $X$ in segment $i$. For the downstream segment 3 , concentrations of constituents in the seaward direction are the boundary conditions denoted $N_{0}, P_{0}$, and $C_{0}$. Inputs from the local watershed and exchange with segments upstream of segment 5 (see Jordan et al. 1991a) are not considered in this analysis. These inputs are negligible because nutrient inputs from the local watershed result in short-lived, localized phytoplankton blooms upstream of the study area, but the volume of water discharged rarely impacts the segments considered here. However, nutrient inputs by exchange with the mainstem Chesapeake Bay are capable of producing blooms of greater spatial extent (Gallegos et al. 1992).

The state variable representing nitrogen available for phytoplankton growth $(N)$ is a combination of the $\mathrm{NO}_{3}\left(+\mathrm{NO}_{2}\right)$ entering at the seaward boundary and the $\mathrm{N}$ (presumably $\mathrm{NH}_{4}$ ) released by the sediments (see below). On average there is a 3 to $4 \mu \mathrm{M}$ pool of dissolved $\mathrm{NH}_{4}$ in the Rhode River (Jordan et al. 1991a), some of which may be regenerated by benthic and water column grazing. This input of dissolved inorganic nitrogen, combined with $\mathrm{NO}_{3}$ entering from across the seaward boundary, influences seasonal net production. Short-term fluctuations in biomass, due to transient imbalances between grazing and growth, are not modeled. 
Table 1 Defintion of symbols used in seasonal model of nutrents and chlorophyll in the Rhode River, Maryland, USA

\begin{tabular}{|c|c|c|}
\hline Symbol & Unit & Description \\
\hline$i, j$ & None & Indices denoting segment numbers; 0 denotes boundary \\
\hline$X$ & $\mu \mathrm{M}$ or $\mathrm{mg} \mathrm{m}^{-3}$ & $\begin{array}{l}\text { Concentration of any state variable in generic mass balance equation for mixing and } \\
\text { uptake or growth }\end{array}$ \\
\hline$S_{i}^{X}$ & Concentration $d^{-1}$ & Net rate of consumption or production of constituent $X$ in segment $i$ \\
\hline$q$ & $d^{-1}$ & Exchange rate between segments $i$ and $j$ \\
\hline$N_{i}$ & $\mu \mathrm{M}$ & Concentration of dissolved inorganic $N$ in segment $i$ \\
\hline$P_{1}$ & $\mu \mathrm{M}$ & Concentration of dissolved inorganic $P$ in segment $i$ \\
\hline$C_{j}$ & $\mathrm{mg} \mathrm{m} \mathrm{m}^{-3}$ & Concentration of phytoplankton chlorophyll $a$ in segment $i$ \\
\hline$B_{i}^{N}$ & $\mu \mathrm{M}$ & Concentration of $\mathrm{N}$ in producing biomass of phytoplankton in segment $i$ \\
\hline$B_{1}^{P}$ & $\mu \mathrm{M}$ & Concentration of $P$ in producing biomass of phytoplankton in segment $i$ \\
\hline$Q_{i}^{N}$ & $\mu \mathrm{M}$ & Concentration of internally stored $\mathrm{N}$ in phytoplankton in segment $i$ \\
\hline$Q_{1}^{P}$ & $\mu \mathrm{M}$ & Concentration of internally stored $\mathrm{P}$ in phytoplankton in segment $i$ \\
\hline$Q_{N}^{\max }$ & None & Factor multiplying $B^{N}$ that determines the maximal internally stored $\mathrm{N}$ \\
\hline$Q_{P}^{m i n}$ & None & Factor multiplying $B^{\mathrm{P}}$ that determines the maximal internally stored $\mathrm{P}$ \\
\hline$f_{0}{ }^{Q N}$ & None & Fraction of $Q_{N}^{\max }$ stored internally by phytoplankton at the seaward boundary \\
\hline$f_{0}{ }^{Q^{P}}$ & None & Fraction of $Q_{p}^{\text {plax }}$ stored internally by phytoplankton at the seaward boundary \\
\hline$N_{0}^{\max x}$ & jiis & Maximal concentration of $\mathrm{N}$ at seaward boundary \\
\hline$t_{\mathrm{m}}$ & None & Day of year at which $N_{0}=N_{0}^{\max } / 2$ \\
\hline$t_{\mathrm{d}}$ & None & Parameter controlling rate of decline of boundary $\mathrm{N}$ \\
\hline$K_{S}^{N}$ & $\mu \mathrm{M}$ & Half-saluration concentration for $\mathrm{N}$ uptake \\
\hline$K_{S}^{\mathrm{P}}$ & $\mu \mathrm{M}$ & Half-saturation concentration for P uptake \\
\hline$K_{Q}^{-N}$ & Núne & 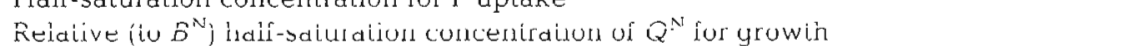 \\
\hline$K_{Q}^{P}$ & None & Relative (to $B^{\mathrm{P}}$ ) half-saturation concentration of $Q^{\mathrm{P}}$ for growth \\
\hline PFD & mol quanta $\mathrm{m}^{-2} \mathrm{~d}^{-1}$ & Underwater photosynthetically available irradiance \\
\hline$T$ & ${ }^{\circ} \mathrm{C}$ & Water temperature \\
\hline$T_{\text {thr }}$ & ${ }^{\circ} \mathrm{C}$ & Threshold temperature for onset of $\mathrm{P}$ release by sediments \\
\hline$r_{i}^{P}$ & $\mathrm{mmol} \mathrm{m} \mathrm{m}^{-2} \mathrm{~d}^{-1}$ & Areal rate of $P$ release by sediments in segment $i$ \\
\hline$r_{r}^{\mathrm{p}}$ & $\mathrm{mmol} \mathrm{m} \mathrm{m}^{-2} \mathrm{~d}^{-1}$ & Areal rate of $\mathrm{P}$ release by sediments at reference temperature of $30^{\circ} \mathrm{C}$ \\
\hline$z_{i}$ & $\mathrm{~m}$ & Depth of segment $i$ \\
\hline$\mu(I, T)$ & $d^{-1}$ & $\begin{array}{l}\text { Maximal, nutrient-saturated phytoplankton growth rate as a function of irradiance } \\
\text { and temperature }\end{array}$ \\
\hline$\mu_{\text {in }}^{\prime}$ & $d^{-1}$ & Nutrient-limited growth rate \\
\hline$\rho_{N}^{\max }$ & $d^{-1}$ & Maximal biomass-specific uptake rate of $\mathrm{N}$ \\
\hline$\rho \max$ & $\mathrm{d}^{-1}$ & Maximal biomass-specific uptake rate of $P$ \\
\hline$\theta_{\mathrm{N}: \mathrm{P}}$ & None & Molar ratio of $N$ to $P$ in the producing biomass of phytoplankton \\
\hline$\theta_{\text {chl a }}$ & $\mu M \mu g^{-1}$ & Yield ratio of phytoplankton biomass $N$ to chlorophyll a \\
\hline$\theta_{\text {s.d }}^{\text {sed }}$ & None & Molar ratio of rate of DIN to P release by sediments \\
\hline
\end{tabular}

\section{Sources and sinks}

The net growth of phytoplankton was modeled using the variable-stores internal-pool model of Riegman \& Mur (1984). In their model, each of the nutrient elements within the phytoplankton is assumed to consist of 2 pools: a biomass pool and an internal storage pool. The biomass pool represents elements in functional (enzymes, pigments, etc) or structural compounds. Elements in the environment must pass through the internal storage pool before being incorporated into biomass. Riegman \& Mur (1984) demonstrated that the growth-nutrient relationships of the cell quota model (Droop 1983) could be derived from the internal pool model, but the formulations are distinctly different because the cell quota of a nutrient is the sum of the internal and biomass pools.
The net source term for the internal nutrient, $Q^{N}$ and $Q^{P}$ for $N$ and P respectively, is the difference between uptake and growth. Using $N$ as an example, the net source term for internally stored $N$ in segment $i, S_{i}^{Q^{N}}$, is

$$
\begin{aligned}
S_{i}^{Q^{N}=} & B^{N} \rho_{N}^{\max }\left(\frac{N}{N+K_{S}^{N}}\right)\left(1-\frac{Q^{N}}{Q_{N}^{\max } B^{N}}\right)- \\
& \mu_{\mathrm{m}}^{\prime} \min \left(Q^{N}, \theta_{N . P} Q^{\mathrm{P}}\right) \\
\mu_{\mathrm{m}}^{\prime}= & \mu(I, T) \min \left(\frac{Q^{N}}{Q^{N}+B^{N} K_{Q}^{N}}, \frac{Q^{\mathrm{P}}}{Q^{\mathrm{P}}+B^{\mathrm{P}} K_{Q}^{\mathrm{P}}}\right) \\
& \min \left(Q_{N}^{\max }, Q_{\mathrm{P}}^{\max }\right)
\end{aligned}
$$

where $B^{N}=$ phytoplankton biomass $N(\mu M), \rho_{N}^{\max }=$ maximal specific uptake rate $\left(\mathrm{d}^{-1}\right), K_{S}^{\mathrm{N}}=$ half-saturation constant for $N$ uptake $(\mu \mathrm{M}), Q_{N}^{\max }=$ maximal storage factor (dimensionless), $\mu_{m}{ }^{\prime}\left(d^{-1}\right)$ is the nutrient-limited specific growth rate, $\mu(I, T)\left(\mathrm{d}^{-1}\right)$ is the nutrient- 
saturated maximal growth rate as a function of irradiance, $I$ (mol quanta $\mathrm{m}^{-2} \mathrm{~d}^{-1}$ ), and temperature, $T\left({ }^{\circ} \mathrm{C}\right)$, $K_{Q}^{N}$ and $K_{Q}^{p}$ (dimensionless) are half-saturation concentrations relative to the producing biomass of $N$ and $P$ respectively, and $\theta_{N: P}=N: P$ molar ratio of the producing biomass. The first term on the right hand side of Eq. (2a) represents nutrient uptake modeled as Monod kinetics with feedback inhibition. The same expression is the sink for dissolved $N$ In general the internally stored pool, $Q$, for the limiting nutrient is only a few percent of the total (i.e. internally stored plus biomass pools; Riegman \& Mur 1984), in which

case the term $\left(1-\frac{Q^{N}}{Q_{N}^{\max } B^{N}}\right)$ is close to 1 . The formula, however, allows for the phenomenon of 'luxury consumption' of the nonlimiting nutrient, limited by a dimensionless factor, $Q_{\mathbb{N}}^{\max }$ (in the case of $N$ ), of the producing biomass

The second term on the right hand side of Eq. (2a), $\mu_{m}{ }^{\prime} \min \left(Q^{N}, \theta_{N: p} Q^{P}\right)$, represents depletion of internally stored $N\left(Q^{N}\right)$ by phytoplankton growth; it is the source term for biomass $N\left(B^{N}\right)$. The minimization in Eq. (2a) assures that $B^{N}$ and $B^{P}$ are produced in the ratio $\theta$, and the first minimization in Eq. (2b) determines that the rate of growth is governed by the internal nutrient in shortest supply relative to cellular demand. For the synthesis of $B^{P}$ from $Q^{P}$, the minimization is $\min \left(Q^{N} / \theta_{N}, Q^{p}\right)$. The denominator of Eq. (2b) converts the calculated rate from a $Q$-specific to a $B$-specific basis. The limitation of growth by light and temperature followed the relationships defining upper bounds we observed in the field data (Gallegos \& Jordan 1997). Because the net production of biomass is limited by $N$ or $P$, and these are maintained in a constant molar ratio in the biomass, the concentration of chlorophyll is modeled simply as proportional to $B^{\mathrm{N}}$, with proportionality constant $\theta_{\text {chl a }}$.

The dissolved nutrient constituents, $N_{1}$ and $P_{1}$ have source terms due to release from the bottom sediments. Jordan et al. (1991a) calculated net rates of DIP production by the segments of the upper Rhode River subestuary. In summer, when $P$ is in excess, these net production rates may approximately equal rates of sediment release. Net rates of $P$ production were highly variable from week to week, ranging from -0.4 to $0.6 \mathrm{mmol} \mathrm{m}^{-2} \mathrm{~d}^{-1}$, with the central tendency varying from 0 to $0.2 \mathrm{mmol} \mathrm{m} \mathrm{m}^{-2} \mathrm{~d}^{-1}$ roughly in phase with the seasonal temperature cycle. We modeled $\mathrm{P}$ release from the sediments, $r_{i}^{\mathrm{P}}\left(\mathrm{mmol} \mathrm{m} \mathrm{m}^{-2} \mathrm{~d}^{-1}\right)$, as a function of temperature for each segment,

$$
r_{i}^{\mathrm{P}}=r_{r}^{\mathrm{P}} \frac{\exp [0.069(T-30)]-\exp \left[0.069\left(T_{\mathrm{thr}}-T\right)\right]}{\left.1-\exp \mid 0.069\left(T_{\mathrm{thr}}-30\right)\right]}
$$

$\left(T \geq T_{\mathrm{thr}}\right)$

$$
r_{1}^{\mathrm{P}}=0 \quad\left(T<T_{\mathrm{thr}}\right)
$$

where $r_{r}^{\mathrm{P}}\left(\mathrm{mmol} \mathrm{m} \mathrm{m}^{-2} \mathrm{~d}^{-1}\right)$ is the areal rate of sediment $P$ release occurring at a reference temperature of $30^{\circ} \mathrm{C}$ and $T_{\text {thr }}$ is a threshold temperature for $P$ release. The constant 0.069 implies a $Q_{10}$ of 2; a threshold temperature of about $7^{\circ} \mathrm{C}$ keeps rates near 0 prior to about early April (see Fig 7 in Jordan et al. 1991a). A similar exponential dependence of $\mathrm{P}$ release rates on temperature was determined by Nixon et al. (1980). Release of $\mathrm{N}$ from the sediment is modeled by an identical expression multiplied by a factor representing the $N$ :P ratio of sediment release, $\theta \mathrm{N}$.P. In this treatment of sediment nutrient release, the concentrations of $\mathrm{N}$ and $\mathrm{P}$ in the sediments are not modeled explicitly.

\section{Boundary conditions and forcing functions}

For easy experimentation with the model we parameterized $N_{0}, C_{0}, I(t)$, and $T(t)$ as simple functions of time. Data in Jordan et al. (1991a) indicate that the weekly averaged concentration of nitrate at the mouth of the Rhode River declines from a peak of about $40 \mu \mathrm{M}$ in early spring to near detection limits in summer, increasing again in mid-September. For the spring decline we chose an empirical function having a sigmoidal approach to 0 ,

$$
N_{0}=\frac{N_{0}^{\max }}{2}\left[1-\tanh \left(\frac{t-t_{\mathrm{m}}}{t_{\mathrm{d}}}\right)\right]
$$

where $N_{0}^{\max }(\mu \mathrm{M})=$ maximal $N$ concentration at the seaward boundary; $t_{m}$, the inflection day, is the day at which $N_{0}=N_{0}^{\max } / 2$; and $t_{\mathrm{d}}$ controls the rate of decline (Fig 2a). A curve with a mirror image controlled the autumnal rise of $N_{0}$.

Boundary condition $C_{0}$ and forcing functions $I(t)$ and $T(t)$ were represented by smoothly varying polynomial fits to field data measured weekly. $C_{0}$ was fit to data measured during 1991 (Fig 2a), a year with chlorophyll concentrations during the spring bloom similar to the long-term averaged data in Fig. 3 of Jordan et al. (1991a). Depth-averaged available irradiance was calculated from daily integrals of incident photon flux recorded at the Smithsonian pier adjacent to segment 4 and diffuse attenuation coefficients interpolated from weekly measurements (Fig. 2b). The temperature function was fit to measurements at a depth of $0.5 \mathrm{~m}$ (Fig 2c). Temperature and irradiance were fit to data measured during 1992, the first year for which phytoplankton growth rates from dilution experiments and a complete season of diffuse attenuation coefficients are available.

Concentration of dissolved phosphate at the boundary is much less variable seasonally than the concen- 

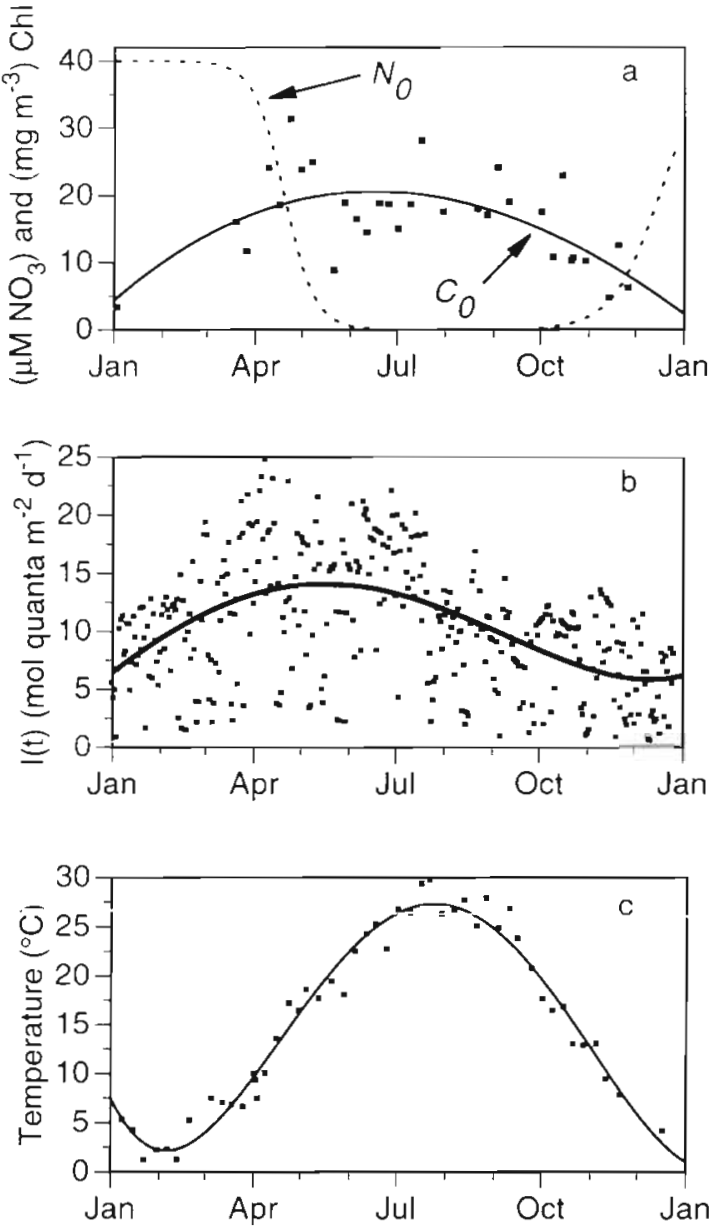

Fig. 2. (a) Smooth curves used to represent concentrations at the seaward boundary: $N_{0}(--)$ and $C_{0}(-)$. Polynomial fit to $C_{0}$ is compared with measurements $(\cdot)$ made in 1991. (b) Calculated in situ PFD ( $)$ ) and polynomial fit (-) used in model. (c) Measured temperatures $(\cdot)$ and polynomial fit $(-)$ used in model

trations in landward segments. We used a constant value of $0.25 \mu \mathrm{M}$ for $P_{0}$, broadly consistent with the data of Jordan et al. (1991a) and Fisher et al. (1992).

Complete equations for segment 4 are given in Table 2. Similar equations hold for the other segments, with minor modifications for mixing and boundary conditions. The model was implemented on a VAX minicomputer in FORTRAN77 using a Runge-Kutta numerical solution with a $0.01 \mathrm{~d}$ time step.

\section{Calibration procedure}

Before using the model to examine different patterns of nutrient inputs, we first calibrated the model to an 'average' year. We determined a plausible set of parameters for the model by a regionalized sensitivity analysis approach (Hornberger \& Cosby 1985), modi- fied to take account of the fact that we have ample measurements of nutrients and chlorophyll, but no direct measurements of most of the physiological parameters or nutrients stored internally by phytoplankton at the seaward boundary. By this procedure, uncertainty in parameter values is incorporated into the estimation procedure by performing a Monte Carlo analysis in which parameters are drawn randomly from defined probability distributions. The predicted output of the simulation for each randomly assigned set of parameter values is then evaluated against a set of rules which define whether or not the output produces the behavior of interest.

We chose as the behavior of interest those sets of parameters that produced 'acceptable representations' of the concentration of chlorophyll observed in segment 4 of the Rhode River in 1991. We chose that year because the magnitude of the spring bloom observed in 1991 was the closest to the long-term average as reported by Jordan et al. (1991a) (Fig. 3). Summer chlorophyll concentrations during 1991 were about half the long-term average, as has been consistently observed during the years in which experiments mentioned above were conducted.

To speed the analysis we restricted the calibration procedure to dates prior to 29 June (Day 180) because the spring bloom is the major feature in the chlorophyll data that diverges from the seaward boundary. The spring bloom in 1991 was defined by a cluster of 3 chlorophyll measurements ranging from 78 to $89 \mathrm{mg} \mathrm{m}^{-3}$ between 17 April and 2 May (Fig. 3). This was followed by a roughly exponential decline over the next $60 \mathrm{~d}$.

Based on the 1991 chlorophyll data (Fig. 3), we defined the 3 following criteria for 'acceptable representation' (Table 3). First, the model must predict a peak chlorophyll concentration within $\pm 10 \%$ of the mean of the cluster of 3 measurements around the peak in the data. Second, the timing of the predicted

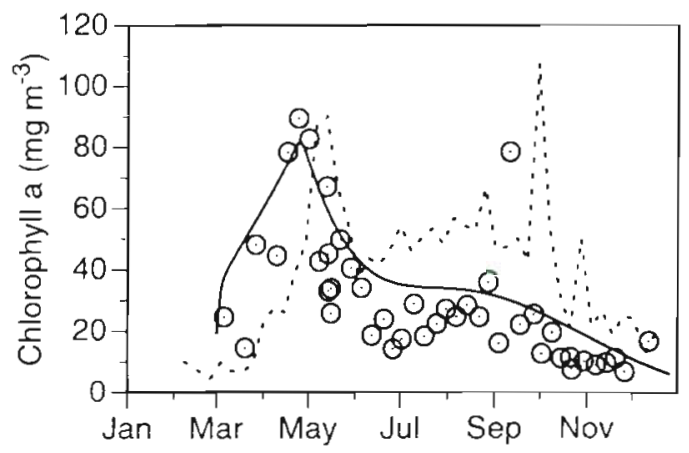

Fig. 3. Time series of chlorophyll concentrations measured in segment 4 of the Rhode River, $1991(\odot)$, compared with model simulation (-). Dashed line is long-term average concentration from Jordan et al. (1991a) 
Table 2. Complete model equations for concentratıons of N, P, internal and biomass nutrients, and chlorophyll $a$, in segment 4 of the Rhode River estuary, Maryland, USA. Definitions of symbols are given in Table 1

\begin{tabular}{|c|c|}
\hline 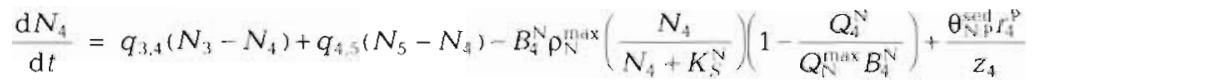 & (5) \\
\hline$\frac{\mathrm{d} Q_{4}^{N}}{\mathrm{~d} t}=q_{34}\left(Q_{3}^{N}-Q_{4}^{N}\right)+q_{4,5}\left(Q_{5}^{N}+Q_{4}^{N}\right)+B_{4}^{N} p_{N}^{\min }\left(\frac{N_{4}}{N_{4}+K_{S}^{N}}\right)\left(1-\frac{Q_{4}^{N}}{Q_{N}^{\min } B_{4}^{N}}\right)-\mu_{111}^{\prime} \min \left(Q_{4}^{N}, \theta_{N} p Q_{4}^{p}\right)$ & (6) \\
\hline$\frac{d B_{4}^{N}}{d t}=q_{3,4}\left(B_{3}^{N}-B_{4}^{N}\right)+q_{4,5}\left(B_{5}^{N}-B_{4}^{N}\right)+\mu_{m}^{\prime} \min \left\langle Q_{i}^{N}, \theta_{N} Q_{4}^{\mu}\right\rangle$ & (7) \\
\hline$\frac{\mathrm{d} P_{4}}{\mathrm{~d} t}=q_{3,4}\left(P_{3}-P_{4}\right)+q_{4,5}\left(P_{4}-P_{4}\right)-B_{4}^{\mathrm{P}} P_{\mathrm{P}}^{\max }\left(\frac{P_{4}}{P_{4}+K_{5}^{\mathrm{p}}}\right)\left(1-\frac{Q_{4}^{\mathrm{p}}}{Q_{\mathrm{P}}^{\max } B_{4}^{\mathrm{p}}}\right)+\frac{r_{4}^{\mathrm{p}}}{z_{4}}$ & (8) \\
\hline$\frac{d Q_{4}^{p}}{d t}=q_{3,4}\left(Q_{3}^{p}-Q_{4}^{\mathrm{p}}\right)+q_{4,5}\left(Q_{5}^{\mathrm{p}}-Q_{4}^{\mathrm{p}}\right)+B_{4}^{\mathrm{p}} \mathrm{p}_{\mathrm{p}}^{\mathrm{pmax}}\left(\frac{N_{4}}{N_{4}+K_{S}^{N}}\right)\left(1-\frac{Q_{4}^{\mathrm{p}}}{Q_{P}^{\max } B_{4}^{\mathrm{p}}}\right)-\mu_{\mathrm{m}}{ }^{\prime} \min \left(Q_{4}^{N} / \theta_{N p}, Q_{4}^{\mathrm{p}}\right)$ & (9) \\
\hline$\frac{\mathrm{d} B_{4}^{\mathrm{p}}}{\mathrm{d} t}=q_{3,4}\left(B_{3}^{\mathrm{p}}-B_{4}^{\mathrm{p}}\right)+q_{4,5}\left(B_{5}^{\mathrm{p}}-B_{4}^{\mathrm{P}}\right)+\mu_{\mathrm{m}}{ }^{2} \min \left(Q_{4}^{\mathrm{N}} / \theta_{\mathrm{N} \cdot \mathrm{P}} Q_{4}^{\mathrm{P}}\right)$ & (10) \\
\hline$C_{4}=\frac{B_{4}^{N}}{\theta_{c h l a t}}$ & (11) \\
\hline$r_{4}^{p}=r_{r}^{p} \frac{\exp \left\{0.069(T-30)|-\exp | 0.069\left(T_{\mathrm{thr}}-T\right) \mid\right.}{1-\exp \left|0.069\left(T_{\mathrm{thr}}-30\right)\right|}$ & (12a) \\
\hline$\left(T<T_{\text {thr }}\right)$ & (12b) \\
\hline$\mu(I, T)=\left(144 \times 10^{0.0275 T-0.7}\right)\left[1-\exp \left(\frac{-(\mathrm{PFD}-3)}{19}\right)\right]$ & (13) \\
\hline$\mu_{\mathrm{m}}^{\prime}=\mu(I, T) \min \left(\frac{Q_{4}^{N}}{Q_{4}^{N}+B_{4}^{N} K_{Q}^{N}}, \frac{Q_{4}^{p}}{Q_{4}^{P}+B_{4}^{\mathrm{P}} K_{Q}^{\mathrm{P}}}\right) / \min \left(Q_{N}^{\max }, Q_{p}^{\mathrm{gpax}}\right)$ & (14) \\
\hline$\rho_{s}{ }^{* x}=\rho_{P}^{\text {max }}=3 \exp (0.069(T-20)]$ & $(15)$ \\
\hline
\end{tabular}

peak must occur within \pm 7 d (i.e. about 1 sampling interval) of the measured peak. Third, the predicted chlorophyll concentration at the termination of the bloom must be $<$ twice the maximal concentration (about $20 \mathrm{mg} \mathrm{m}^{-3}$ ) observed during the final $3 \mathrm{wk}$ of the bloom period. This last criterion is somewhat liberal because the model systematically overestimated chlorophyll concentrations during the end of the bloom. The systematic overestimation may be due to slight overestimation of the boundary chlorophyll concentration during this period (cf. Fig. 2a) or due to unrepresented losses of chlorophyll.

We first selected a trial set of parameters based on published values or, when available, previous measurements on the Rhode River (Table 4). We then conducted a Monte Carlo simulation by drawing 1000 sets of parameters from random distributions with limits of $\pm 40 \%$ of the trial value. Sensitivity of the model calibration to a particular parameter can be judged by how much the values producing the desired behavior differ from those which do not (Hornberger \& Cosby 1985). We found it useful to distinguish 3 types of parameter sets: those that met the behavior-defining criteria, those that underestimated (predicted maximum < $65 \mathrm{mg} \mathrm{m}^{-3}$ ) and those that overestimated (simulated maximum $>120 \mathrm{mg} \mathrm{m}^{-3}$ ) peak chlorophyll.

\section{RESULTS AND DISCUSSION}

\section{Calibration of the model to an average year}

A single simulation with the trial set of parameters (Table 4) produced output that qualitatively resembled the data, but failed 2 of the 3 acceptance criteria by predicting a peak chlorophyll concentration of $112 \mathrm{mg}$ $\mathrm{m}^{-3}$ (i.e. too high) on 1 May (acceptable), and a decline to $51.2 \mathrm{mg} \mathrm{m}^{-3}$ (too high) by 29 June (Table 3). How- 
Table 3. Criteria used to select model parameters producing 'acceptable representation' of chlorophyll concentrations observed during the spring bloom of 1991 in segment 4 of the Rhode River, Maryland (USA). Units: chlorophyll concentrations, mg m ;

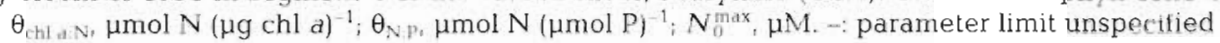

\begin{tabular}{|c|c|c|c|c|c|c|}
\hline $\begin{array}{l}\text { Criterion } \\
\text { no. }\end{array}$ & $\begin{array}{c}\text { Predicted behavior or } \\
\text { parameter }\end{array}$ & $\begin{array}{l}\text { Minimum } \\
\text { acceptable }\end{array}$ & $\begin{array}{l}\text { Maximum } \\
\text { acceptable }\end{array}$ & $\begin{array}{l}\text { Measured } \\
\text { data, } 1991\end{array}$ & $\begin{array}{c}\text { Trial } \\
\text { parameters }\end{array}$ & $\begin{array}{l}\text { Calibrated } \\
\text { parameters }\end{array}$ \\
\hline \multicolumn{7}{|c|}{ Criteria dependent on model predictions } \\
\hline 1 & Maximum chl a & 75 & 92 & 89.3 & 112 & 82.3 \\
\hline 2 & Date on which chl a peaks & 14 Apr & 1 May & 24 Apr & 1 May & $25 \mathrm{Apr}$ \\
\hline 3 & Chl a concentration on 29 June & - & 40 & 17.0 & $51.2^{t}$ & 35.4 \\
\hline \multicolumn{7}{|c|}{ Criteria dependent on parameter values } \\
\hline 4 & $\theta_{\text {chian }}$ & 0.38 & - & & & \\
\hline 5 & $\theta_{N P}$ & - & 19 & & & \\
\hline 6 & $N_{0}^{\max }$ & - & 80 & & & \\
\hline
\end{tabular}

Table 4. Values of parameters used in initial model run with literature source or justification, and value determined by comparing results of Monte Carlo simulations varying parameter $40 \%$ above and below its trial value with data observed in 1991 . Units of parameters are given in Table 1

\begin{tabular}{|c|c|c|c|}
\hline Parameter & Trial value & Source/justification & prated value \\
\hline$\theta_{N: P}$ & 16 & Goldman et al. (1979) & 18.15 \\
\hline$\theta_{\text {chl } \approx}$ & 0.38 & Based on C:chl $\alpha=30, C: N=106: 16$ & 0.483 \\
\hline$Q_{N}^{\max }$ & 0.7 & Andersen et al. (1991), internal storage capacity of $\mathrm{N}$ less than that for $\mathrm{P}$ & 0.55 \\
\hline$Q_{p}^{\text {thax }}$ & 3 & Mackereth (1953), storage capacity of $\mathrm{P}$ for up to 4 doublings & 2.47 \\
\hline$f_{0}{ }^{Q^{N}}$ & $\frac{N_{0}}{N_{0}+K_{S}^{N}}$ & $\begin{array}{l}\text { Fisher et al. (1992), physiological indicators of } \mathrm{N} \text { limitation parallel seasonal } \\
\mathrm{N} \text { depletion }\end{array}$ & \\
\hline$f_{y j} Q^{p}$ & 0.71 & Jordan et al. (1991a), boundary DIP concentration relatively constant & 0.57 \\
\hline$K_{Q}^{N}$ & 0.05 & $\begin{array}{l}\text { Riegmann \& Mur (1984), internal concentration of limiting nutrient is only few } \\
\text { percent of biomass nutrient }\end{array}$ & 0.055 \\
\hline$K_{Q}^{\mathrm{P}}$ & 0.05 & $\begin{array}{l}\text { Riegmann \& Mur (1984), internal concentration of limiting nutrient is only few } \\
\text { percent of biomass nutrient }\end{array}$ & 0.044 \\
\hline$K_{\mathrm{S}}^{\mathrm{N}}$ & 2.0 & Fisher et al. (1992) & 2.30 \\
\hline$K_{5}^{\mathrm{P}}$ & 0.125 & $=K_{S}^{N} / \theta_{N: P}$ & 0.127 \\
\hline$N_{0}^{\max }$ & 60 & Unpublished measurements of spring freshet, April 1992 & 52.5 \\
\hline$t_{\mathrm{m}}$ & 105 & Inspection of measured $\mathrm{NO}_{3}$, spring 1991 & 104 \\
\hline$t_{\mathrm{d}}$ & 30 & Inspection of measured $\mathrm{NO}_{3}$, spring 1991 & 26 \\
\hline$r_{r}^{p}$ & 0.15 & Fig. 7 in Jordan et al. (1991a), average mud-summer rate & 0.128 \\
\hline$T_{\text {the }}$ & 7.0 & Fig. 7 in Jordan et al. (1991a), average P release rate $\approx 0$ prior to mid-May & 7.5 \\
\hline$\rho_{N}^{\max }, \rho_{P}^{\max }$ & 3 & Goldman et al. (1979), specific uptake rate exceeds specific growth rate & $3.0^{\mathrm{d}}$ \\
\hline$\theta$ sed & 4 & $\begin{array}{l}\text { Jordan et al. (1991a), average N:P of particulate organic matter discharged from } \\
\text { local watershed }\end{array}$ & $2.0^{b}$ \\
\hline \multicolumn{4}{|c|}{${ }^{\circ}$ Parameter not varied } \\
\hline
\end{tabular}

ever, the 1000 Monte Carlo simulations produced 25 runs meeting the 3 concentration and timing criteria. From these 25 runs we selected a subset with 3 parameters within a range of values well documented in the literature (Table 3). Two of these parameters pertained to compositional ratios of phytoplankton, for which there are ample culture studies (Goldman et al. 1979, Caperon 1982), and the third relates to the concentration of DIN at the seaward boundary, which rarely exceeds $90 \mu \mathrm{M}$ at the upper Bay (Fisher et al.
1992). Five simulations met all criteria. From these, we selected 1 parameter set (Table 4 ) which combined $\theta_{N \text { P }}$ closest to 16 and timing of the peak chlorophyll closest to 24 April, the day of the observed maximum (Fig. 3). This parameter set, which produced the most realistic model run, was used for examining the seasonal sensitivity to $N$ and $P$ additions. We chose the run with $\theta_{N \text { P }}$ closest to 16 because the model will be most sensitive to this parameter when ample nutrients are present to produce new chlorophyll, which is the condition under 
which growth rate will be maximal and compositional ratios should approach the Redfield value (Goldman et al. 1979, Caperon 1982).

The dominant feature of the annual cycle of phytoplankton pigment biomass in the Rhode River in 1991 was the spring bloom (Fig. 3), which began to accumulate about 15 March, peaked on 27 April, and had terminated by 30 May. The model with plausible parameters (Table 4) reproduced the essential features of the bloom. A local minimum in the data that was not reproduced in the model occurred near 29 June, which is probably associated with a shift of community dominance from dinoflagellates to cryptomonads and other autotrophic microflagellates (Malone et al. 1988, Gallegos 1992), or other loss processes (sedimentation, senescence) not incorporated in the model. Similarly, there was an ephemeral autumnal bloom which was present in only 1 sampling and was localized to segment 4 (Gallegos unpubl.). The source of nutrients for this bloom was unobserved and, hence, not modeled.

We calibrated the N:P ratio of sediment nutrient flux $(\theta$ sed. Table 4) by adjustment, because $\theta$ N.P affected simulated mid-summer chlorophyll concentrations, but not the magnitude of the spring bloom. Simulation with the trial value of $\theta{ }_{N p}^{\text {sed }}$ produced mid-summer chlorophyll concentrations similar to the long-term average, but as noted, mid-summer chlorophyll concentrations in 1991 were about half the long-term average. After fixing the first 14 parameters by the regionalized sensitivity analysis, we determined the $N: P$ ratio of sediment nutrient release by decreasing $\theta \underset{\mathrm{N}: \mathrm{s}}{\mathrm{sed}}$ until simulated chlorophyll concentrations passed through measurements made during August and September (Fig 3). Interestingly, the N:P of sediment release that produced the closest chlorophyll simulation (Table 4) is close to the ratio of total particulate N:P discharged by the local watershed (i.e. 2.7, inferred from Figs. 8 \& 9 in Jordan et al. 1991a). Low N:P ratio of sediment nutrient flux is evidently common in shallow coastal systems, and may reflect denitrification in the sediments (Nixon et al, 1980) as well as the N:P ratio in particulate matter from the watershed.

\section{Indicators of nutrient limitation}

The simulated ratio of DIN:DIP in the parameterized model was much greater than the Redfield ratio (16) prior to early April (Fig. 4a), indicating likely limitation by $P$ during winter and early spring. The ratio dropped rapidly in April, falling below 16 on 9 April, and remained well below 1 , indicating potentially severe $\mathrm{N}$ limitation, the remainder of the year.

In the model, the nutrient most limiting to growth rate is determined by the supply of internal nutrients,
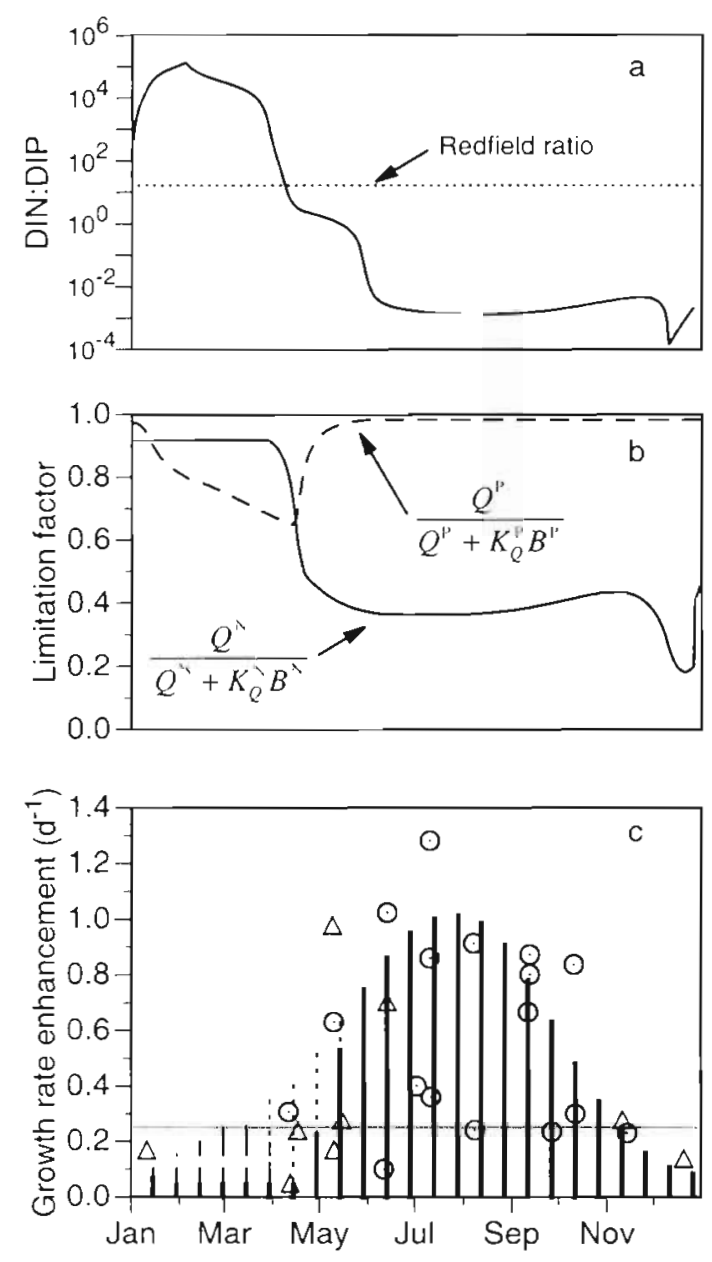

Fig. 4. Seasonal progression of simulated indicators of nutrient limitation. (a) Ratio of simulated DIN:DIP. Ratio first falls below Redfield value (16) on 11 Apr. (b) Time series of nutrient limitation factors based on internal nutrient concentrations for nitrogen $\left(Q^{N},-\right)$ and dissolved inorganic phosphorus $\left(Q^{P},--\right)$. Limitation factors intersect on $17 \mathrm{Apr}$. (c) Model calculations of enhancement of net growth rate by addition of $\mathrm{P}$ alone (- -), $\mathrm{N}$ alone (-), or $\mathrm{N}$ and $\mathrm{P}$ together (- - ). Measured enhancement of growth rates (Gallegos \& Jordan 1997) from 1993 to 1996 due to addition of $P(\Delta)$ alone and $N(\odot)$ alone are given for comparison. Overall magnitude of simulated enhancement is similar to measurements, but more regular. Horizontal dotted line is the $0.25 \mathrm{~d}^{-1}$ change detection limit for experimentally measured growth rate increments (Gallegos \& Jordan 1997)

$Q^{N}$ and $Q^{P}$, relative to growth requirements (Eq. $2 b$ ). The seasonal progression of the limitation factors for $\mathrm{N}$ [i.e. $\left.Q^{N} /\left(Q^{N}+K_{Q}^{N} B^{N}\right)\right]$ and $P\left[Q^{P} /\left(Q^{P}+K_{Q}^{P} B^{P}\right)\right]$ also indicates $P$ limitation in winter and early spring (Fig. 4b). The internal nutrient in shortest supply changes from $Q^{P}$ to $Q^{N}$ on 15 April, $6 \mathrm{~d}$ after the ratio of DIN:DIP drops below the Redfield ratio, so that there is only a brief time when internal and external pools give a conflicting indication of the identity of the limiting nutrient 
We tested the model for the effects of nutrient enrichment by adding either $64 \mu \mathrm{M} N$ or $4 \mu \mathrm{MP}$, or both, to the computed concentrations at 45 d intervals, which was sufficient time for the effects of one nutrient addition to subside before addition of the next pulse. Net growth rate was calculated from the $1 \mathrm{~d}$ change in predicted chlorophyll concentration in the same way as in dilution experiments (Gallegos \& Jordan 1997). Three such runs with the first nutrient additions commencing $15 \mathrm{~d}$ apart were done for each nutrient (or both combined) to determine the response over the annual cycle (Fig 4c).

Addition of $P$ ajone in the model stimulated net growth rate from 15 January through 30 March, but the enhancement was generally less than the $0.25 \mathrm{~d}^{-1}$ detection limits of the dilution experiments of Gallegos \& Jordan (1997). Addition of $\mathrm{N}$ alone enhanced calculated net growth rate from 30 April through the end of the year, with the increment exceeding $0.25 \mathrm{~d}^{-1}$ from 15 May through about 30 October (Fig. 4c). Co-limitation occurred during a brief period when computed nutrient limitation factors for both $\mathrm{N}$ and $\mathrm{P}$ were depressed from their saturated values (cf. Fig. 4b, c). On 4 calculated dates (31 March through 15 May) addition of both $\mathrm{N}$ and $\mathrm{P}$ stimulated growth rates to a greater extent than either $\mathrm{N}$ or $\mathrm{P}$ alone, but only on 15 April was the stimulation $>0.25 \mathrm{~d}^{-1}$ above that due to the primary limiting nutrient (Fig. 4c).

The model, parameterized to fit observed chlorophyll concentrations in the Rhode River in 1991, also reproduced the general pattern of net growth rate limitation observed in the data (Fig. 4c, data points). As in the data, enhancement of net growth rate by addition of $\mathrm{P}$ alone occurred early in the year when maximal growth rates were constrained by irradiance and temperature. In an average year, addition of $\mathrm{P}$ to a $\mathrm{P}$-limited system therefore had less impact on net growth rate than did addition of $\mathrm{N}$ to an $\mathrm{N}$-limited system. However, even small growth enhancements that would be undetectable experimentally can have large effects on biomass. An enhancement of net growth rate by $0.2 \mathrm{~d}^{-1}$ would not be experimentally measurable, but leads to an order of magnitude increase in biomass in $<12 \mathrm{~d}$, about the time scale over which the spring bloom develops (Fig. 3). We conclude, therefore, that the rate of $\mathrm{P}$ supply is an important control on bloom development in the early spring.

The model predicted that, in an average year, there would be only a brief period when growth enhancement from adding $\mathrm{N}$ and $\mathrm{P}$ together would exceed enhancement from adding the most-limiting nutrient singly. Our 1 d incubation experiments (Gallegos \& Jordan 1997) were not designed to test for co-limitation. Stimulation of growth by addition of $\mathrm{N}$ and $\mathrm{P}$ together in mid-summer appears to be common in some systems such as Delaware Bay (Pennock \& Sharp 1994); but our modeling evidence suggests that $c o$-limitation by $N$ and $P$ in the Rhode River is too uncommon to detect without a well-timed full factorial experiment.

\section{Simulation of interannual variability in limiting factors}

In the Rhode River, the spring bloom can fail to develop in different years either due to insufficient $N$ or to insufficient P (Gallegos et al. 1997). Parameter sets in the model that produced simulations resembling years with insufficient. $\mathrm{N}$ were characterized by low nitrate concentration and early nitrate depletion at the seaward boundary, and by high chlorophyll:nitrogen ratios in the phytoplankton (Gallegos et al. 1997). Simulations resembling years with insufficient $P$ were characterized by high and persistent nitrate concentrations at the seaward boundary, and by low sediment $P$ release rates (Gallegos et al. 1997).

In years lacking spring blooms, patterns of stimulation by $\mathrm{P}$ and $\mathrm{N}$ additions differed according to the cause of bloom failure (Fig. 5). In 1993, Susquehanna River flow was unusually high, sustaining detectable levels of nitrate at the Rhode River into mid-June as water temperature rose above $20^{\circ} \mathrm{C}$ (Fig. 5a). That year, addition of $P$ alone to dilution incubations in mid-May and mid-June enhanced net growth rate by $>0.7 \mathrm{~d}^{-1}$ (Fig. 5b), which was more than any other enhancements due to $\mathrm{P}$ addition alone (cf. Fig. 4c). Simulations of years with insufficient $\mathrm{P}$ correctly predicted that enhancement by $\mathrm{P}$ additions is greatest in late spring (Fig. 5c). The model also predicted that insufficient $\mathrm{P}$ would delay and prolong the period of co-limitation by both $\mathrm{P}$ and $\mathrm{N}$ during midsummer (cf. Figs. 4c \& 5c). In the experiments, we did not compare additions of both $\mathrm{N}$ and $\mathrm{P}$ with additions of $N$ or P alone (Gallegos \& Jordan 1997), but we found that growth rate enhancements due to addition of $\mathrm{N}$ alone during the summer of 1993 were lower than in most years (cf. Figs. $4 \& 5 b, e$ ).

Conditions of insufficient $\mathrm{N}$ are typified by 1995 when concentrations of $\mathrm{NO}_{3}$ were low in the spring and $\mathrm{NO}_{3}$ was depleted prior to May while water temperatures were still $<15^{\circ} \mathrm{C}$ (Fig. $5 \mathrm{~d}$ ). That year a slight, but insignificant, enhancement of growth rate by $P$ addition was measured in mid-April, just prior to the depletion of $\mathrm{NO}_{3}$ (Fig. 5e). Also, $\mathrm{N}$ addition alone resulted in substantial enhancement of growth rate in mid-May (Fig. 5e), much earlier than in a year of insufficient P (e.g. 1993). The simulation of insufficient $N$ indicated possible co-limitation by $\mathrm{N}$ and $\mathrm{P}$ in midApril (Fig. 5f). The model correctly simulated growth rate enhancement due to $\mathrm{N}$ addition in mid-May, as well as generally higher levels of enhancement due to 

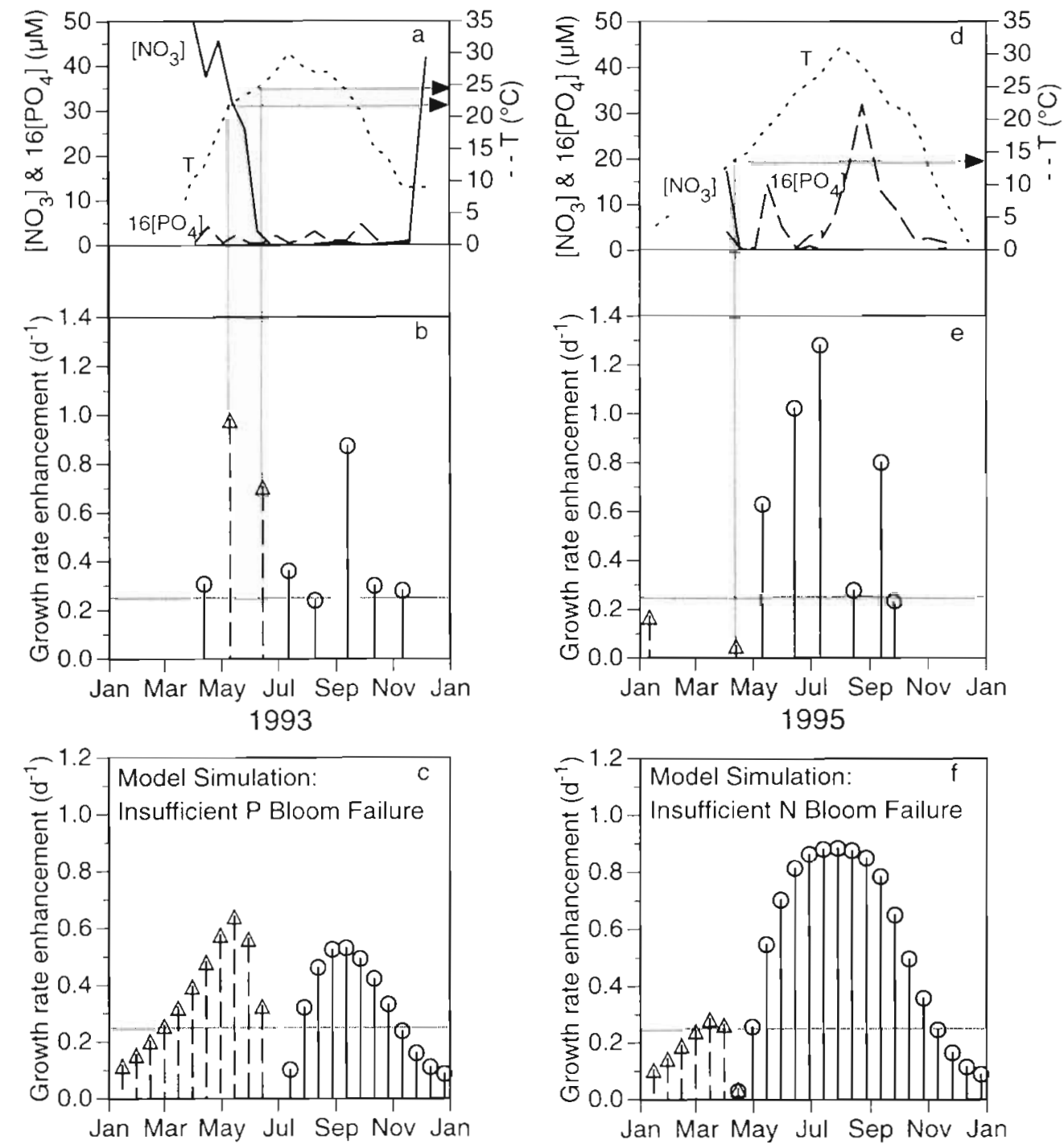

Fig. 5. (a) Time series of $\mathrm{NO}_{3}(-)$ and $\mathrm{PO}_{4}(---)$ concentrations, and water temperature $(-\cdots)$ in the Rhode River in 1993 , a year in which the spring bloom failed to occur due to insufficient $\mathrm{P} . \mathrm{PO}_{4}$ concentrations are multiplied by 16 (the Redfield ratio for $\mathrm{N}: \mathrm{P}$ ) to scale on the same axis with $\mathrm{NO}_{3}$. (b) Measured enhancement of growth rate due to addition of $P$ alone $(\Delta,-\cdots)$ or $N$ alone $(O$, -) in 1993. The arrows connect the enhancement due to $\mathrm{P}$ addition to the water temperature during the period when $\mathrm{NO}_{3}$ is in excess. (c) Model preduction of enhancement due to addition of $\mathrm{P}$ or $\mathrm{N}$ (symbols as in b) using model parameters that characterize years with bloom failures due to insufficient $P$ (see Gallegos et al. 1997). Departures from a smooth curve governed by temperature and PFD (cf. Fig. 4c) are times when both P and N limit growth. (d) and (e) as in (a) and (b) respectively, but for 1995, a year in which the spring bloom failed to occur due to insufficient $N$. (f) as in (c), except with parameters that characterize years with bloom fallures due to insufficient $N$ (see Gallegos et al. 1997). Horizontal dotted lines in (b). (c). (d), and (f) are the 0.25 d ${ }^{\prime}$ change detection limit for experimentally measured growth rate increments (Gallegos \& Jordan 1997)

$N$ addition throughout the summer, compared with years having insufficient $P$ during spring.

\section{Manipulation of nutrient sources}

In the model there are 3 allochthonous sources of each nutrient available for net production of new phytoplankton biomass: dissolved nutrient at the seaward boundary, particulate nutrient stored internally within the phytoplankton at the boundary, and dissolved nutrient released from the sediment. The timing of the inputs and relative amounts of nutrients from each source have the potential to induce a temporal shift from $\mathrm{P}$ to $\mathrm{N}$ limitation. At the seaward boundary, the simulated N:P ratio of dissolved nutrient drops below 

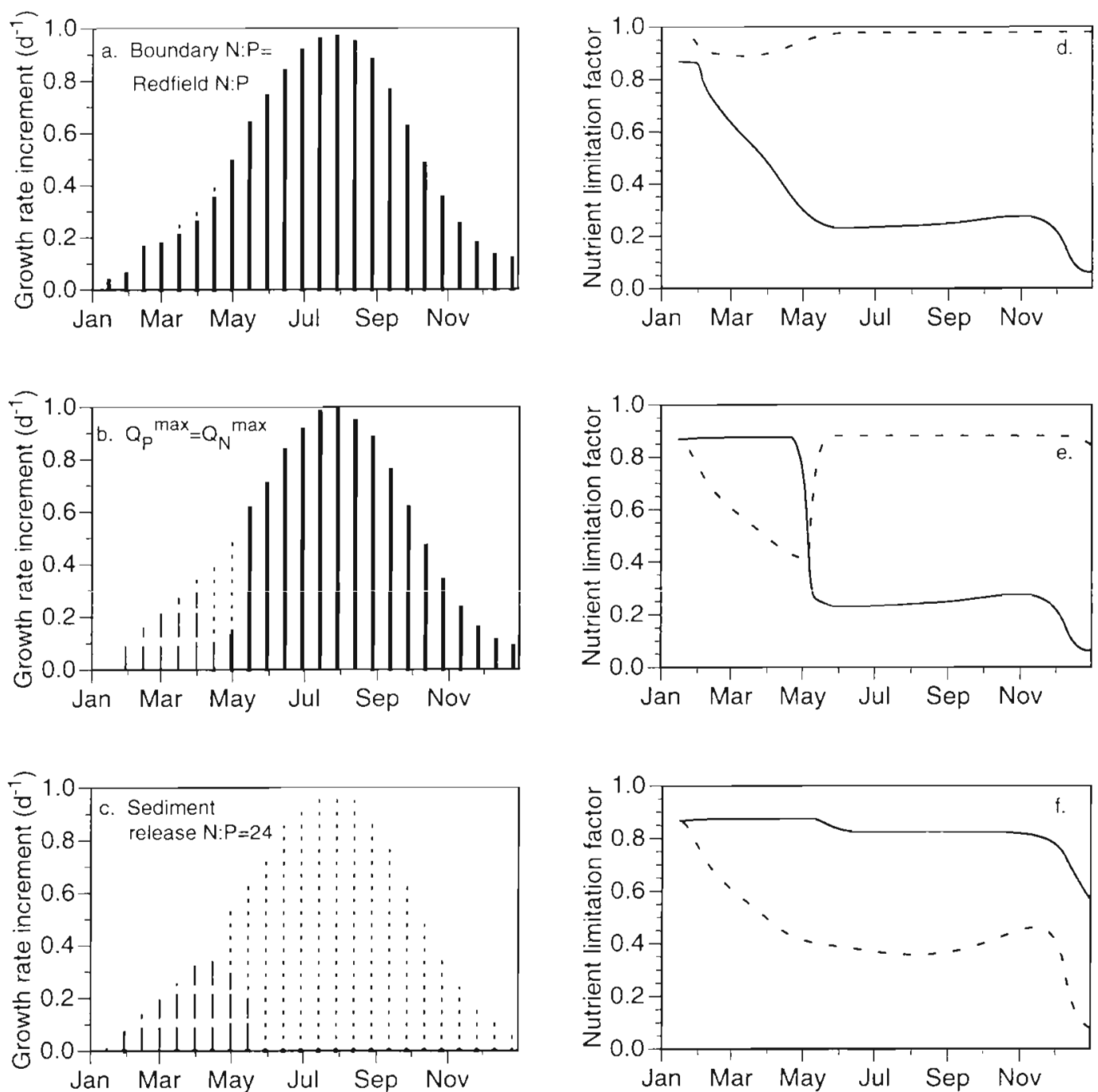

Fig. 6. (a $-\mathrm{c})$ Model calculations of enhancement of net growth rate by addition of $\mathrm{P}$ alone (- - ), $\mathrm{N}$ alone ( - ), or $\mathrm{N}$ and $\mathrm{P}$ together $(--)$ for different manipulations of the allochthonous nutrient supplies. (a) Dissolved N:P ratio at the seaward boundary $=\theta_{N}$ of phytoplankton biomass; (b) excess $P$ at the seaward boundary eliminated, i.e. $N_{0}: P_{0}=4$, boundary $Q^{N}: Q^{P}=\theta_{N: P}$, and $Q_{P}^{m a x}=Q_{N}^{m a x}$; (c) N:P ratio of sediment release $\left(\theta_{N}^{\text {sed }}\right)=24$, and boundary flux of $Q^{N}$ and $Q^{p}$ balanced. (d-f) Time series of simulated nutrient limitation factors based on internal nutrient concentrations: (-) N limitation factor; (- - -) P limitation factor. Scenarios for (d), (e), and (f) are as those in (a), (b), and (c), respectively

that of algal biomass, $\theta_{N: P}$ by 1 May. Similarly, the ratio of $\mathrm{N}: \mathrm{P}$ released from sediment used in the model was much less than that of algal biomass, and the capacity for internal storage by phytoplankton, including those at the boundary, was greater for P than for $\mathrm{N}$.

We manipulated these nutrient sources in the model to identify the factors that may cause the seasonal shift from $\mathrm{P}$ to $\mathrm{N}$ limitation. For example, by maintaining the boundary $N_{0}: P_{0}$ ratio equal to $\theta_{N \text { p }}$ of the phytoplankton, we found that $N$ limitation occurred all year (Fig. 6a). That is, if the boundary P supply were adequate for balanced growth, then internally stored $P$ and sediment release would be sufficient to supply $P$ in excess all year. By setting the boundary $N_{0}: P_{0}$ ratio equal to 4 (i.e. $\ll \theta_{N}$ ), and eliminating excess internally stored $\mathrm{P}$ in boundary phytoplankton i.e. bound$\operatorname{ary} Q^{N}: Q^{P}=\theta_{N: P}$ and $Q_{P}^{\text {max }}=Q_{N}^{\text {max }}$ ), we found that local sedimentary $P$ release, given the calibrated. $\theta N$ sed, was sufficient to induce a shift from $\mathrm{P}$ to $\mathrm{N}$ limitation by 30 April (Fig. 6b). This scenario resembled the average year (cf. Figs. 4c \& 6b). None of the scenarios examined caused the system to display enhancement of growth rate by $\mathrm{P}$ addition alone in the summer, because of the near-complete disappearance of DIN at the seaward boundary in the summer (Jordan et al. 1991a, Fisher et al. 1992). As a result, setting parameter values that would have seemed to force $P$ limitation, i.e. $\theta$ sed $p=24$, $P_{0}=N_{0} / 4 \theta_{N}: P_{\text {, }}$ and $Q_{\mathrm{P}}^{\max }=Q_{N}^{\max }$, resulted in prediction 
of P limitation only through 15 April, and co-limitation the remainder of the year after depletion of DIN at the boundary (Fig, 6c).

In the scenarios where $N_{0}: P_{0}=\theta_{N}$, and $N_{0}: P_{0}=4$, the predictions of nutrient limitation based on internally stored $N$ and P, i.e.

$$
\frac{Q^{N}}{Q^{N}+B^{N} K_{Q}^{N}} \text { and } \frac{Q^{P}}{Q^{P}+B^{P} K_{Q}^{P}}
$$

were the same as those based on the simulated growth response experiments (Fig. 6d, e). In the scenario where $\theta_{N: P}^{\text {sed }}=24$, internally stored $\mathrm{P}$ was in shorter supply relative to growth requirements than internally stored $N$ from April onward (Fig. 6f), and yet addition of $\mathrm{P}$ alone in the model never enhanced calculated net growth rate. Evidently, the simulated sediment $N$ release rate was sufficient to nearly saturate internal stores of $\mathrm{N}$, but, unlike stored $\mathrm{P}$, the stored $\mathrm{N}$ (Table 4) was insufficient to support significant growth when dissolved $\mathrm{P}$ was added without simultaneous addition of dissolved $\mathrm{N}$.

Experimentation with the model revealed that excess P from any of the 3 sources (i.e. constant boundary DIP, boundary $Q^{P}$, and sediment release) was sufficient to cause the net growth rate of phytoplankton to be $\mathrm{N}$ limited in summer. However, the presence of excess DIN in winter and early spring was necessary for the model to simulate $\mathrm{P}$ limitation at those times (Fig. 6a). The modeled disappearance of DIN at the boundary in late spring assures that addition of $\mathrm{P}$ alone will never stimulate net growth rate in the summer. Given that the model simulated $N$ limitation all year with a balanced N:P at the seaward boundary, it is easy to see that the same result would occur if the seaward boundary were depleted of $\mathrm{N}$ year round, as has been shown in some estuaries with a large coastal influence (Rudek et al. 1991). Similarly, we expect that simulation of persistent freshwater inflow with high N:P at the head would establish gradational zones from $\mathrm{P}$ to $\mathrm{N}$ limitation, as observed in Norwegian coastal waters (Sakshaug \& Olsen 1986) and simulated experimentally in mesocosms (Doering et al. 1995).

\section{Summary}

This work has demonstrated how modeling can help reveal environmental processes underlying temporal shifts in experimentally identified limiting nutrient. These shifts result from the temporal patterns of allochthonous $\mathrm{N}$ and $\mathrm{P}$ supplied from remote watersheds, local sediments and, though not included here, local watersheds (Jordan et al. 1991a, b) and the atmosphere (Paerl et al. 1990). Nutrient stored internally by phytoplankton arriving at the seaward bound- ary is also potentially an important determinant of temporal patterns. In general, the model indicated that there would usually be agreement amongst indicators of nutrient limitation based on ratios of available nutrients, indicators of physiological status, and growth response to nutrient additions. An exception was a case in which internally stored nutrients might suggest $P$ limitation at times when addition of $P$ alone would not stimulate growth. Overall, the success of the model at reproducing results of short-term experiments in addition to monitored field data lends additional confidence to use of the model for investigating processes underlying interannual variability and long-term trends in phytoplankton biomass.

Acknowledgements. This research was supported by the Smithsonian Environmental Sciences Program. We thank Pat Neale for comments on an earlier version of the paper, $\mathrm{S}$. Hedrick for assistance with the experiments, and J. Miklas for collection of long-term nutrient and pigment data.

\section{LITERATURE CITED}

Andersen T, Schartau AKL, Paasche E (1991) Quantifying external and internal nitrogen and phosphorus pools, as well as nitrogen and phosphorus supplied through remineralization, in coastal marine plankton by means of a dilution technique. Mar Ecol Prog Ser 69:67-80

Caperon J (1982) Some interactions of biogeochemical cycles in the marme environment. In: Freney JR, Galbally IE (eds) Cycling of carbon, nitrogen, sulfur and phosphorus in terrestral and aquatic ecosystems. Springer-Verlag, New York, p 143-150

Doering PH, Oviatt CA, Nowicki BL, Klos EG, Reed LW (1995) Phosphorus and nitrogen limitation of primary production in a simulated estuarine gradient. Mar Ecol Prog Ser 124: $271-287$

Droop MR (1983) 25 years of algal growth kinetics. A personal view. Bot Mar 26:99-112

Elser JJ, Frees DL (1995) Microconsumer grazing and sources of limiting nutrients for phytoplankton growth: application and complications of a nutrient-deletion/dilution-gradient technique. Limnol Oceanogr 40:1-16

Fisher TR, Peele ER, Ammerman JW, Harding LWJ (1992) Nutrient limitation of phytoplankton in Chesapeake Bay. Mar Ecol Prog Ser 82:51-63

Gallegos CL (1989) Microzooplankton grazing on phytoplankton in the Rhode River, Maryland: nonlinear feeding kinetics. Mar Ecol Prog Ser 57:23-33

Gallegos CL (1992) Photosynthesis, productivity, and species composition in a eutrophic sub-estuary: comparison of bloom and bon-bloom assemblages. Mar Ecol Prog Ser 81 $257-267$

Gallegos CL, Jordan TE (1997) Seasonal progression of factors limiting phytoplankton pigment biomass in the Rhode River estuary, Maryland (USA). I. Controls on phytoplankton growth. Mar Ecol Prog Ser 161:185-198

Gallegos CL, Jordan TE, Correll DL (1992) Event-scale response of phytoplankton to watershed inputs in a subestuary: timing, magnitude, and location of phytoplankton blooms. Limnol Oceanogr 37:813-828 
Gallegos CL, Jordan TE, Correll DL (1997) Interannual variability in spring bloom timing and magnitude in the Rhode River, Maryland (USA): observations and modeling. Mar Ecol Prog Ser 154:27-40

Goldman JC, McCarthy JJ, Peavey DG (1979) Growth rate influence on the chemical composition of phytoplankton in oceanic waters. Nature 279:210-215

Han GC (1974) Salt balance and exchange in the Rhode River a tributary embayment to the Chesapeake Bay. PhD thesis, The Johns Hopkins University, Baltimore

Holm-Hansen O, Lorenzen CJ, Holmes RW, Strickland JDH (1965) Fluorometric determination of chlorophyll. J Cons Perm Int Explor Mer 30:3-15

Hornberger GM, Cosby BJ (1985) Selection of parameter values in environmental models using sparse data: a case study. Appl Math Comput 17:335-355

Jeffrey SW, Humphrey GF (1975) New spectrophotometric equations for determining chlorophyll $a, b, c 1$, and $c 2$ in higher plants, algae and natural phytoplankton. Biochem Physiol Pfl 167:191-194

Jordan TE, Correll DL, Miklas J, Weller DE (1991a) Nutrients and chlorophyll at the interface of a watershed and an estudry. Limnol Oceanogr 36:251-267

Jordan TE, Correll DL, Miklas J, Weller DE (1991b) Longterm trends in estuarine nutrients and chlorophyll, and short term effects of variation in watershed discharge. Mar Ecol Proq Ser 75:121-132

Landry MR, Hassett RP (1982) Estimating the grazing impact of marine micro-zooplankton. Mar Biol 67:283-288

Mackereth FJ (1953) Phosphorus utilization by Asterionella formosa Hass. J Exp Bot 4:296-313

Malone TC, Crocker LH, Pike SE, Wendler BW (1988) Influences of river flow on the dynamics of phytoplankton pro-

Editorial responsibility: Otto Kinne (Editor),

Oldendorf/Luhe, Germany duction in a partially stratified estuary. Mar Ecol Prog Ser $48: 235-249$

Nixon SW, Kelly JR, Furnas BN, Oviatt CA, Hale SS (1980) Phosphorus regeneration and the metabolism of coastal marine bottom communities. In: Tenore KR, Coull BC (eds) Marine benthic dynamics. University of South Carolina, Columbia, p 219242

Officer CB, Biggs RB, Taft JL, Cronin LE, Tyler MA, Boynton WR (1984) Chesapeake Bay anoxia: origin, development. and significance. Science 223:22-27

Paasche E, Erga SR (1988) Phosphorus and nitrogen limitation of phytoplankton in the inner Oslofjord (Norway). Sarsia 73:229-243

Paerl HW, Rudek J, Mallin MA (1990) Stimulation of phytoplankton production in coastal waters by natural rainfall inputs: nutritional and trophic implications. Mar Biol 107: $247-254$

Pennock JR, Sharp JH (1994) Temporal alternation between light-and nutrient-limitation of phytoplankton production in a coastal plain estuary. Mar Ecol Prog Ser 111:275-288

Riegman R, Mur LR (1984) Theoretical considerations on growth kinetics and physiological adaptation of nutrientlimited phytoplankton. Arch Microbiol 140:96-1.00

Rudek J, Paerl. HW, Mallin MA, Bates PW (1991) Seasonal and hydrological control of phytoplankton nutrient limitation in the lower Neuse River Estuary, North Carolina. Mar Ecol Prog Ser 75:133-142

Sakshaug E, Olsen Y (1986) Nutrient status of phytoplankton blooms in Norwegian waters and algal strategies for nutrient competition. Can J Fish Aquat Sci 43:389-396

Schubel JR, Kennedy VS (1984) The estuary as a filter: an introduction. In: Kennedy VS (ed) The estuary as a filter Academic Press, Orlando, p 1-11

Submitted: November 26, 1996; Accepted: November 17, 1997 Proofs received from author(s): December 23, 1997 


\title{
Impacts of high-nitrate freshwater inputs on macrotidal ecosystems. I. Seasonal evolution of nutrient limitation for the diatom-dominated phytoplankton of the Bay of Brest (France)
}

\author{
Yolanda Del Amo ${ }^{1, *}$, Olivier Le Pape ${ }^{2}$, Paul Tréguer $^{1}$, Bernard Quéguiner $^{1}$, \\ Alain Ménesguen ${ }^{2}$, Alain Aminot ${ }^{2}$ \\ 'UMR CNRS 6539 'Bioflux', Université de Bretagne Occidentale, Institut Universitaire Européen de la Mer, \\ Technopole Brest-Iroise, Place Nicolas Copernic, F-29280 Plouzané, France \\ ${ }^{2}$ Laboratoire 'Chimie et Modélisation des Cycles Naturels', Direction de l'Environnement Littoral, IFREMER, BP 70 ,
} F-29280 Plouzané, France

\begin{abstract}
The chemical factors (inorganic nitrogen, phosphate, silicic acid) that potentially or actually control primary production were determined for the Bay of Brest, France, a macrotidal ecosystem submitted to high-nitrate-loaded freshwater inputs (winter nitrate freshwater concentrations $>700 \mu \mathrm{M}$, Si:N molar ratio as low as 0.2 , i.e. among the lowest ever published). Intensive data collection and observations were carried out from February 1993 to March 1994 to determine the variations of physical [salinily, temperature, photosynthetically active radiation (PAR), freshwater discharges] and chemical (oxygen and nutrients) parameters and their impacts on the phytoplankton cycle (fluorescence, pigments, prmary production). With insufficient PAR the winter stocks of nutrients were almost nonutilized and the nitrate excess was exported to the adjacent ocean, due to rapid tidal exchange. By early April, a diatom-dominated spring bloom developed (chlorophyll a maximum $=7.7 \mu \mathrm{g} \mathrm{l}^{-1}$; primary production maximum $=2.34 \mathrm{~g} \mathrm{C} \mathrm{m}^{-2} \mathrm{~d}^{-1}$ ) under high initial nutrient concentrations. Silicic acid was rapidly exhausted over the whole water column; it is inferred to be the primary limiting factor responsible for the collapse of the spring bloom by mid-May. Successive phytoplankton developments characterized the period of secondary blooms during summer and fall (successive surface chlorophyll a maxima $=3.5$, 1.6, 1.8 and $1.0 \mu \mathrm{g} \mathrm{I}^{-1}$; primary production $=1.24,1.18$ and $0.35 \mathrm{~g} \mathrm{C} \mathrm{m}^{-2} \mathrm{~d}^{-1}$ ). Those secondary blooms developed under lower nutrient concentrations, mostly originating from nutrient recycling. Until August, Si and $\mathrm{P}$ most likely limited primary production, whereas the last stage of the productive period in September seemed to be $N$ limited instead, this being a period of total nitrate depletion in almost the whole water column. Si limitation of spring blooms has become a common feature in coastal ecosystems that receive freshwater inputs with Si:N molar ratios $<1$ The peculiarity of Si limitation in the Bay of Brest is its extension through the summer period.
\end{abstract}

KEY WORDS: Coastal ecosystem - Phytoplankton dynamıcs Macrotıdal - Nutrient limitation Sulicon Eutrophication

\section{INTRODUCTION}

The long-term increase of anthropogenic inputs of nitrogen and phosphorus into the coastal waters of most developed countries (Howarth et al. 1996) has 3

\footnotetext{
- Present address: Department of Ecology, Evolution and Marine Biology, Marine Science Institute, University of California, Santa Barbara, Californı 93106, USA.

E-mail: delamo@lifesci.lscf.ucsb.edu
}

potential consequences. First, it can induce a spectacular enhancement of the productivity of phytoplankton populations that were previously $N$ and/or $P$ limited, leading to severe eutrophication problems (Meybeck \& Helmer 1989, Smayda 1990). Second, declines in dissolved Si:N ratios in coastal waters can induce subsequent silicic acid ( $=$ 'silicates') limitation of diatomdominated populations (Officer \& Ryther 1980, Smayda 1990, Conley \& Malone 1992, Conley et al. 1993). Third, this Si limitation can disturb the typical suces- 